\title{
УДК 378.016:78.071.2
}

\section{ІНФОРМАЦІЙНИЙ ЕТАП НАВЧАННЯ МАЙБУТНІХ УЧИТЕЛІВ МУЗИКИ МУЛЬТИМЕДІЙНОГО АРАНЖУВАННЯ}

\section{Степанов В. А.}

У статті окреслено основні напрямки роботи на формувальному етапі навчання майбутніх учителів музики мультимедійного аранжування з урахуванням міждисциплінарного та герменевтичного підходів. Подано аналіз наукових досліджень щодо методичної і теоретичної підготовки майбутнього вчителя музики та використання мультимедійних технологій у процесі їх фрахової підготовки. Акцентовано роль музично-теоретичних дисциплін, розкрито сутнісний зміст понять "слух музиканта" та "полістилістика".

Актуалізовано значення навчання мультимедійного аранжування у підготовці фахівия, який відповідає сучасним вимогам до особистості вчителя музики. Підкреслено формування аксіологічно-ціннісних орієнтацій та музичноестетичного смаку майбутніх учителів музики, необхідність розширення досвіду сприймання музики різних стилів та жанрів. Визначено комплекс спеціальних фрахових компетенцій для створення вдалого аранжування та етапи мультимедійного аранжування музичного твору. Розкрито значення співвіднесення розвитку музичного слуху та узагальнення набутих теоретичних знань і практичних умінь у контексті реалізації поставлених творчих завдань.

Результати формувального експерименту в межах статті представлено на прикладі реалізації методики навчання мультимедійного аранжування майбутніх учителів музики на інформаційному етапі. Окреслено необхідні для процесу навчання мультимедійного аранжування загально-дидактичні $і$ специфрічні принципи, методи, колективні форми роботи, які застосовувалися на зазначеному етапі дослідження.

Ключові слова: фрахова підготовка, слух музиканта, компетениії, слухацький досвід, музично-теоретичні дисципліни, музично-естетичний смак.

В статье очерчены основные направления работы на формирующем этапе обучения будущих учителей музыки мультимедийной аранжировке. Проанализированы научные исследования относительно методической и теоретической подготовки будущих учителей музыки. Подчёркнуто значение музыкальнотеоретических дисциплин в фрормировании их аксиологично-ценностных ориентаций и музыкально-эстетического вкуса. Определён комплекс необходимых компетенций и этапы мультимедийной аранжировки музыкального произведения. Результаты формирующего эксперимента в рамках статьи представлено на примере реализации методики обучения мультимедийной аранжировке студентов на информационном этапе. Освещены принципы, методы, коллективные фрормы работы, использовавшиеся на этом этапе исследования.

Ключевые слова: профрессиональная подготовка, слух музыканта, компетенции, слушательский опыт, музыкально-теоретические дисциплины, музыкальноэстетический вкус.

The article outlines the main directions of work at the formative stage of the training of future music teachers of multimedia arrangement taking into account interdisciplinary and hermeneutical approaches. The analysis of scientific researches concerning the methodical and theoretical education of the future teacher of music and the use of multimedia technologies in the process of their professional training is given. The importance of learning multimedia arrangements in the process of training a specialist that meets the modern requirements for the personality of the music teacher is actualized.

The role of music theory subjects is emphasized, the essence of the concepts of "musician's ear" and "polystylistics" is revealed. The formation of axiological orientations 
and the musical and aesthetic taste of future music teachers, the necessity to expand the experience of perception of music of various styles and genres is actualized. A set of special professional competencies for creating successful arrangements and stages of multimedia arrangement of a musical composition has been defined. The significance of correlation of the development of musical ear and generalization of the acquired theoretical knowledge and practical skills in the context of realization of the assigned creative tasks is revealed.

The results of the forming experiment within the article are presented on the example of the implementation of the method of teaching the multimedia arrangement of future music teachers at the informational stage. Necessary for the process of teaching multimedia arrangement general-didactic and specific principles, methods, collective forms of work that were used at the specified stage of the research are outlined.

Key words: professional training, musician's ear, competencies, listening experience, music theory subjects, musical and aesthetic taste.

Постановка проблеми. "За експертними оцінками, найбільш успішними на ринку праці в найближчій перспективі будуть фахівці, які вміють навчатися впродовж життя, критично мислити, ставити цілі та досягати їх, працювати в команді, спілкуватися в багатокультурному середовищі та володіти іншими сучасними вміннями" [6, с. 4]. Підготовка таких фрахівців на сьогоднішній день вимагає реформування змісту, методів, засобів, організаційних форм навчання, принципової модернізації всього науково-методичного забезпечення навчально-пізнавального процесу. У зв'язку з цим на сучасному етапі актуалізується питання визначення методів, форм, засобів, які забезпечують ефективність процесу фрахової підготовки майбутніх учителів музичного мистецтва, зокрема, особливої уваги заслуговує проблема застосування мультимедійних засобів навчання.

Аналіз останніх досліджень і публікацій. Питання методичної і теоретичної підготовки майбутнього вчителя музики висвітлювали Ю. Алієв, О. Апраксіна, А. Барвінова, Н. Гребенюк, Н. Гузій, А. Козир, Ю. Локарєва, Л. Масол, О. Олексюк, Г. Падалка, Г. Побережна, О. Ростовський, О. Рудницька, В. Федоришин, Т. Щериця, О. Щолокова.

Зокрема, А. Козир, В. Федоришин зазначають, що професійне формування майбутнього вчителя має розглядатись у контексті його особистісного акмеологічного становлення [2]. Т. Щериця зауважує, що одними з найважливіших залишаються проблеми теоретичної підготовки майбутніх учителів й ефрективності її використання у практичній діяльності [9]. У працях Л. Масол, О. Олексюк, Г. Падалки, О. Щолокової підкреслюється значення компетентнісного підходу.

Використання мультимедійних технологій у процесі фрахової підготовки майбутніх учителів музики досліджували Г. Александрова, О. Барицька, Л. Гаврилова, Ю. Локарєва, О. Павленко, В. Шинкаренко, О. Чайковська та ін. Предметом дослідження М. Абакумова, В. Бєлунцова, І. Гайденка, Е. Денисова, Д. Скрипкіна, І. Стецюка, В. Ценової була проблема використання сучасних комп'ютерних технологій у музичній творчості. Питання аранжування музичних творів засобами комп'ютерних технологій розглядали Л. Варнавська, В. Луценко, О. Солдатенко, питання формування творчих якостей засобами комп'ютерних технологій Ю. Дворнік.

Водночас аналіз наукових джерел, проведене дослідження показує, що питання впровадження мультимедійних технологій у процес фахової підготовки майбутніх учителів музики розкриті недостатньо. Звертаючи увагу на вагомість даної проблеми, актуалізуємо значення навчання мультимедійного аранжування у підготовці фрахівця, який відповідає сучасним вимогам до особистості вчителя музики.

Метою статті $€$ окреслення основних напрямків роботи на фрормувальному етапі навчання майбутніх учителів музики мультимедійного аранжування 3 урахуванням міждисциплінарного та герменевтичного підходів.

Виклад основного матеріалу. Навчання мультимедійного аранжування видається студентам суто технічним процесом. Формуванню такого враження, 
зокрема, сприяє інформація з мережі Інтернет, де пропонується безліч пропозицій щодо аранжування музичних творів. Насправді йому передує, а потім продовжується протягом навчання у ВН3, процес постійної роботи над собою - набуття музичнотеоретичних знань, розширення досвіду сприймання музики різних стилів та жанрів, емпатії, ресрлексії, інтерпретації музичного твору, розвитку музичних здібностей, формування ціннісно-світоглядних мистецьких орієнтацій, постійне удосконалення музично-естетичного смаку задля художньо-естетичної спрямованості майбутньої педагогічної діяльності.

Процес аранжування твору, як зазначають науковці (зокрема, Л. Гаврилова, О. Солдатенко), відбувається у певній послідовності і потребує сформованості певних компетенцій. На основі наукових досліджень і виходячи з власного досвіду роботи, ми визначаємо три основні етапи мультимедійного аранжування. На першому етапі з'являється задум і уявлення звучання майбутнього твору (кінцевого результату втілення ідеї майбутньої композиції); другий етап - власне процес аранжування (перекладення, інструментовка, оркестровка, набір нот тощо); третій етап - слухання готового твору і корекція звучання (урахування стилістики твору, особливостей використання інструментів у композиції, органічності сполучення тембрів за допомогою комп'ютерних програм).

Для вдалого аранжування потрібен комплекс спеціальних фрахових компетенцій, як-от: уміння аналізувати музичний твір з точки зору його фактурного викладу, форми, стилю, жанрових особливостей; знання музичних ключів, строїв, закономірностей тембрових сполучень інструментів, основних ритмічних формул різних танцювальних ритмів, що сполучаються з навичками їх застосовування. Створення аранжування передбачає наявність композиторських здібностей та вмінь, розвиненого гармонічного слуху, музично-інтонаційного, образно-асоціативного і поліфонічного мислення, навичок імпровізації, адже інколи приходиться писати вступ і коду, зв'язки-інтермедії між куплетами (частинами композиції), а також умінь грамотно записати створений твір або набрати його в програмі-нотаторі.

Ураховуючи наведені вище положення, на інформаційному етапі формувального експерименту роботу спрямовуємо на набуття студентами слухацького досвіду, зокрема, жанрово-стильових уявлень; розвиток музично-інтонаційного, поліфонічного та образно-асоціативного мислення; накопичення необхідних для створення аранжування знань, опанування відповідним тезаурусом. Основна увага зосереджувалася на фрормуванні аксіологічно-ціннісних орієнтацій та музичноестетичного смаку майбутніх учителів музики.

Ми спиралися на попередній досвід та знання, отримані студентами у процесі вивчення музично-теоретичних дисциплін, починаючи з першого курсу, зокрема: сольфеджіо, гармонії, поліфонії, стильової гармонізації, аналізу музичних творів, теорії та історії художньої культури, хорового аранжування, музичної інформатики. Адже, як зазначає Ю. Локарєва, комплекс музично-теоретичних дисциплін "повинен забезпечувати формування музичного мислення студентів (зокрема, образноасоціативного), розвиток відповідних аналітично-слухових навичок сприйняття, розширення кола слухових уявлень та слухового досвіду, художньо-естетичного світогляду, музичних смаків, особистісної музичної культури, творчого потенціалу" $[4$, c. 234]. Важливим у нашій роботі був також рівень підготовки студентів 3 основного музичного інструменту, ансамблю, хорового та оркестрового класу.

Отже, навчання майбутніх учителів музики мультимедійному аранжуванню ми проводили з позицій міждисциплінарного підходу, який забезпечує співвіднесення розвитку музичного слуху та узагальнення набутих теоретичних знань і практичних умінь з означених дисциплін у контексті реалізації поставлених творчих завдань.

Ураховуючи усе вищезазначене, у процесі наповнення змісту занять ми звертали увагу студентів на явища полістилістики у сучасній музиці. Полістилістика це "зумисне поєднання в одному творі несумісних, або надзвичайно відмінних, різнорідних стилістичних елементів" [10, с. 204]. Основними ї̈ формами є колаж, цитата, псевдоцитата, ілюзія, алюзія, натяк тощо. Але до явищ полістилістики не відносяться: чужа тема у варіаціях, народна мелодія або імітація в народному стилі, інструментовка твору іншого композитора, деякі види цитат, невитриманість стилю [5]. 
Зближення різних жанрів і стилів $є$ ознакою сучасного музичного мистецтва, про що свідчать дослідження у галузі мистецтвознавства. Так, С. Коробецька зазначає: "В оркестровій музиці другої половині $\mathrm{XX}$ століття й на початку XXI спостерігається певна зупинка радикального експериментування 3 оновленням інструментарію та тенденція до синтезу різних стилів та жанрів. Зокрема, увага композиторів перемикається у сфреру синтезу звуку, в електронну музику. Загальне ж річище творчих пошуків складають полістилістика та стильовий синтез як провідні тенденції сучасного музичного процесу" [3, с. 60].

На хід процесу створення аранжування, як показала практика, впливає така якість студентів, як готовність до експериментування та імпровізації, яка у сполученні із креативністю і здатністю до аналізу значно підвищує його ефективність. Варто відзначити у цьому зв'язку роль музичного слуху, який ми розглядаємо у студента фракультету мистецтв з відповідним рівнем музичної підготовки - майбутнього вчителя музики, педагога-музиканта, - як "слух музиканта". Як зазначає М. Старчеус, одним з найважливіших щодо слуху музиканта виступає поняття "відчуття" (ладу, ритму, висоти), котре лише частково співпадає з поняттям "слух". Це поняття, на думку вченої, акцентує психологічний механізм і специфіку слуху музиканта і $є$ операціональним, а не афективним феноменом [7].

Слух музиканта відрізняється від слуху звичайної людини (за М. Старчеус) тим, що у музикантів слух більш тонко, вибірково і багатозначно пов'язаний із руховою сферою, із уявою та мисленням. У музикантів деякі якості слуху формуються в процесі профресійного музичного навчання. Саме тому в них відмічається високий рівень слухового контролю та оцінки, більш глибока залежність слухової діяльності від деяких індивідуально-особистісних якостей.

Важливою в контексті нашого дослідження є думка Б. Асаф'єва стосовно слуху, який "стає мірою речей в музиці" [1, с. 207]. Переживання "єдності Звуку та Смислу як музичної властивості слуху" в інтонаційній теорії Б. Асаф'єва пов'язуються із закономірностями людського інтонування як прояву думки, оскільки зміст завжди пов'язаний з інтонацією, утворюючи звуко-образний смисл. 3 інтонуванням пов'язана як мовна специффіка музики, так і її соціальне побутування та історичний розвиток. Науковцем введено поняття "інтонаційний словник" (кожна епоха виробляє у різних жанрах "символічні" інтонації (звукокомплекси), зображальні формули, "штампи", що викликають певні асоціації, які варто віднести до галузі музичної семантики [1, с. 207-208], а також "інтонаційне поновлення", яке забезпечується переосмисленням існуючих інтонаційних лексем (найменших смислових одиниць музичної мови, - за аналогією словесної лексеми).

Розвиток навичок слухового розрізнення таких стійких музичних формул, музично-стильових зворотів у процесі сприймання музики, що сприяє розвитку образно-асоціативного мислення, $є$ необхідним, адже аранжування музичного твору потребує від студентів детального вивчення музичного тексту (твору сучасного композитора, класичного твору, народної пісні, бардівської мелодії, дитячої пісні тощо), який має свою історичну лексикологію, структуру, властивості.

Власна інтерпретація тексту має бути кінцевим результатом їх творчої роботи, у ході якої народжується те саме "відчуття" ладу, ритму, висоти (яке відзначала М. Старчеус, розглядаючи слух музиканта) обраної мелодії, відчуття характерних інтонацій (лексем, на які вказували Б. Асафф'єв, а потім і В. Медушевський, В. Холопова та інші науковці). Глибокий художньо-образний та жанрово-стильовий аналіз спричиняє розуміння музичного тексту, що приводить до виникнення задуму і втілення його у процесі створення аранжування.

Як відомо, розуміння виявляється через інтерпретацію, в якій розкривається рівень інтелекту, освіченості, духовного розвитку інтерпретатора. Тому аналіз музичних творів ми проводили 3 позицій герменевтичного підходу, коли інтерпретація та розуміння текстів забезпечуються герменевтичним колом, методиками запитань та відповідей, контекстним методом, спеціальними логічними засобами, семіотичними та психологічними прийомами, чим доповнюється традиційний теоретичний аналіз. Упродовж реалізації поетапної методики, нами акцентувалися розвиток музично-естетичного смаку та набуття слухацького досвіду студентів, який розширювався завдяки слуханню та аналізу яскравих обробок, аранжувань, 
транскрипцій, стилізацій класичних музичних творів, популярних пісень відомих виконавців, дитячих пісень.

Матеріалом для слухання слугували: 1) варіації та транскрипції композиторівкласиків (Н. Паганіні, Ф. Ліст, С. Рахманінов, В.-А. Моцарт); 2) стилізації та сучасні обробки музичної класики (М. Скорик, С. Прокоф'єв, Б. Буєвський, Ю. Юрченко); 3) аранжування дитячих пісень сучасних українських композиторів (П. Мережин, Н. Май, А. Мігай); 4) різні обробки одного й того ж твору на прикладах двох українських народних пісень "Щедрик" та "Ой, ходить сон", а також "Іспанського болеро" В. Кьяра, полонезу М. Огіньського, "Жарту" И.-С. Баха, танго А. П'яцоли.

Серед колективних форм роботи, які застосовувалися нами на інформаційному етапі, найкраще зарекомендували себе лекції-диспути та дискусії 3 обов'язковим прослуховуванням зазначених музичних творів, їхніх обробок і обговоренням особливостей аранжування за допомогою інтерактивних методів та прийомів (групова дискусія, "круглий стіл", "мікрофон", "мозковий штурм"). У ході експериментальної роботи дотримувалися принципів системності, активності, диференціації, діалогічності навчання, його естетичної спрямованості та рефлективності, принципу єдності емоційного і свідомого.

Ураховувалися нами також і особливості вітчизняної художньої культури, в якій останнім часом поглиблюється розшарування на елітарну, що позиціонує себе як атрибут високого соціального статусу (мистецтво для "інтелектуалів"), та масову, розраховану на легке "споживання", орієнтовану на фрінансовий успіх, із свідомим "спрощенням" засобів виразності. Це пов'язано з вибором не художніх, а економічних критеріїв до оцінювання мистецтва, що веде до його свідомої комерціалізації [8]. Відповідно майбутній вчитель музики має розуміти, до яких творів він буде звертатися у своїй майбутній діяльності, що буде пропонувати своїм учням, формуючи їхні мистецькі уподобання.

Висновки. Отже, окреслені напрямки роботи, реалізовані у відповідності до авторської методики навчання мультимедійного аранжування майбутніх учителів музики на формувальному етапі експериментального дослідження, сприяли систематизації музично-теоретичних знань, забезпечували розвиток творчої активності, навичок всебічного теоретичного аналізу музичних творів, фрормування музично-естетичного смаку студентів, що дозволяло їм визначати та пропонувати своє художньо-звукове бачення, виявлене у виконаних творчих завданнях. Висвітленню результатів впровадження означеної методики на всіх етапах фрормувального експерименту будуть присвячені наші подальші публікації.

\section{Література}

1. Асафьев Б. В. Музыкальная форма как процесс / Б. В. Асафьев ; ред. Е. М. Орловой. - Л. : Музыка, 1971. - 376 с.

2. Козир А. В. Вступ до акмеології мистецької освіти : навч.-метод. посіб. / А. В. Козир, В. І. Федоришин. - К. : Вид-во НПУ імені М. П. Драгоманова, 2012. - 263 с.

3. Коробецька С. Ю. Жанрово-стильовий синтез як ознака сучасної вітчизняної оркестрової музики / С. Ю. Коробецька // Єдність навчання і наукових досліджень головний принцип університету : зб. наук. праць звітно-наукової конференції викладачів університету за 2012 рік, 9-10 лютого 2013 року / уклад. Г. І. Волинка, О. В. Уваркіна, О. П. Ємельянова. - К. : Вид-во НПУ імені М. П. Драгоманова, 2013. - 403 с. - С. 60-62.

4. Локарєва Ю. Особливості музично-теоретичної підготовки у професійному становленні майбутнього вчителя музики / Ю. Локарєва // Наукові записки Кіровоградського державного педагогічного університету імені Володимира Винниченка. Серія "Педагогічні науки". - 2012. - Вип. 112. - С. 229-236.

5. Музыкальный энциклопедический словарь / глав. ред. Г.В.Келдыш. - М. : Советская энциклопедия, 1990. - 672 с.

6. Нова українська школа. Концептуальні засади реформування середньої школи [Електронний ресурс] / упоряд.: Л. Гриневич, О. Елькін, С. Калашнікова та ін. ; заг. ред. М. Грищенко. - МОН, 2016. - 40 с. - Режим доступу:

https://www.kmu.gov.ua/storage/app/media/reforms/ukrainska-shkola-compressed.pdf. - Назва з екрана. 
7. Старчеус М. С. Слух музыканта: психолого-педагогические проблемы становления и совершенствования : автореф. дисс. ... д-ра пед. наук : спец. 13.00.08, 19.00.01 / Старчеус М. С. - М., 2005. - 433 с.

8. Українське мистецтво кінця $\mathrm{XX}$ - початку XXI ст. [Електронний ресурс]. Режим доступу:

http://pidruchniki.com/1256060757045/kulturologiya/ukrayinske mistetstvo kintsya pochatku XXI. - Назва з екрана.

9. Щериця Т. В. Музично-теоретична підготовка вчителя музики / Тамара Володимирівна Щериця // Проблеми сучасної педагогічної освіти : зб. ст. Сер. "Педагогіка і психологія". - Ялта : [Б. в.], 2006. - Вип. 12. - Ч. 2. - С. 160-165.

10. Юцевич Ю. Є. Музика : словник-довідник / Ю. Є. Юцевич. - Тернопіль : Навчальна книга - Богдан, 2003. - 352 с. 